\title{
Perspectives on Salutogenesis of Scholars Writing in Swedish
}

\author{
Monica Eriksson
}

\section{Introduction}

In 1987-1988 Aaron Antonovsky spent a year as visiting professor at the University of Lund, invited and hosted by Professor Marianne Cederblad. This has influenced the development of the Swedish researchSwedish salutogenesis research in a decisive way. His stay in Sweden gave the Swedish researchers an opportunity to personally meet and discuss the salutogenic model of health. It gave inspiration and encouraged researchers to conduct salutogenic research in Sweden. According to Antonovsky, cited in Hansson and Cederblad (1995), the Swedish version translated from the English version of the sense of coherence questionnaire was developed by Lisa Dahlin, Margareta Furu, and Carol Tishelman, at the University of Lund in consultation with Aaron Antonovsky, as the standard version to be used in Sweden.

Two research groups emerged as pioneers in the early Swedish research on salutogenesis. The research team led by Marianne Cederblad and Kjell Hansson at the University of Lund (with colleagues at the Department of Child and Adolescent Psychiatry) conducted groundbreaking research on salutogenesis in the treatment of families and children at risk for developing mental illnesses. Their early cross-sectional studies were followed by longitudinal studies with various time intervals for follow-ups (Cederblad, 1996; Cederblad, Dahlin, \& Hagnell, 1994; Dahlin et al., 1990; Dahlin \& Cederblad, 1993).

The research group in nursing at the Karolinska Institute in Stockholm, headed by Professor Hjördis Björvell and

\footnotetext{
M. Eriksson $(\bowtie)$

Department of Health Sciences, Section of Health Promotion and Care Sciences, Center on Salutogenesis, University West, Gustava Mellinsgata 2, SE-46186 Trollhättan, Sweden

e-mail: monica.eriksson@hv.se
}

Professor Ann Langius Eklöf (Langius \& Björvell, 1993, 1996, 2001; Langius, Björvell, \& Antonovsky, 1992) focused on validating the sense of coherence questionnaire in the Swedish context, both in the general population of Swedes and also among different patient groups.

During his stay in Lund, Antonovsky held lectures at the former Nordic School of Public Health (NHV) in Gothenburg, invited by another front figure in salutogenesis, Professor Bengt Lindström. Here Antonovsky introduced the salutogenic model of health to a Nordic audience of students and professionals. Professor Lindström was at the same time working with his doctoral thesis on the quality of life of Nordic children, adopting a salutogenic approach (Lindström, 1994). In an address at NHV in 2006, Lindström highlighted the valuable contribution of Antonovsky for Nordic research in general and Swedish research in particular (Lindström, 2006). For many years thereafter university courses in salutogenesis were organized at NHV. Students and professionals from the Nordic countries became inspired and encouraged to adopt the salutogenic approach in their different contexts. Inspired by the contacts with Antonovsky, other university courses in salutogenesis were started, for example at the Karolinska Institute in Stockholm. In sum, Antonovsky's visiting year in Lund influenced Swedish research on salutogenesis in a very positive way.

\section{Research Seminars}

In 1998, the Swedish Research Council organized a crosssectional scientific conference on the salutogenic concept of the sense of coherence. Active researchers in the field of salutogenesis were invited to participate. A conference report was produced by (Kumlin, 1998), who was inspired to critically analyze the salutogenic research by Antonovsky, and giving mainly a negative critique focused on many issues. He claimed the salutogenic theory was (a) full of contradictions, (b) that Antonovsky had created a new 
dichotomy between the salutogenic and pathogenic perspective, both excluding the other, (c) that the salutogenic theory did not contribute to the understanding and explanation of health, and (d) the theory did not represent any new perspective on health. Kumlin's pathogenic examination of the salutogenic concept was presented to 15 senior researchers, who all individually responded in written statements (and also collectively) pronouncing many of Kumlin's statements as being unfair and lacking substance (Röster om kasam, 1998).

The experts were scientists who for decades had conducted research based on the salutogenic theory. In addition, many of them had met Antonovsky, and therefore had the opportunity to engage in direct detailed discussions about the salutogenesis and its constructs. Cederblad (1998) raised the question of what makes a theory valuable for research. One way is to empirically test it. She explicitly pointed out that Kumlin ignored the results of all the empirical studies on the sense of coherence concept. Instead, he chose some kind of scientific theoretical analysis. Konarski (1998) objected to Kumlin's vendetta and how Kumlin tried to marginalize Antonovsky and his ambitions as a scientist.

Ten years later, the first international research seminar on salutogenesis was arranged in Helsinki, followed by annual international meetings and seminars in the Nordic countries and national Swedish conferences in Trollhättan.

\section{Research on Salutogenesis Arouses Interest}

A systematic search was undertaken in ProQuest (hosting 12 separate scientific databases) per February 11, 2016, for scholarly journals, dissertations, and thesis in the time span 1983-2016, using the sense of coherence, salutogenesis, and Antonovsky (separate search on each word) as the search strategy. This resulted in 3894 hits, out of which at least 530 papers included Sweden in the title or abstract. Searching on dissertations and student theses at different levels in Swedish shows there are at least 334 publications in the period 1983-2015. There are publications from different disciplines such as medicine, nursing, health sciences, public health, psychology, and social work. A systematic research synthesis showed that in 1992-2003, at least 85 different Swedish samples were investigated in salutogenesis research (Eriksson, 2007). Yet, most of the research on salutogenesis in Sweden is published in English. Table 48.1 shows a selection of papers on the salutogenic concepts published in Swedish.

The focus of previous research on salutogenesis in Sweden was to introduce the salutogenic health model to Swedish researchers, and thereafter translate and develop the
Swedish version of the sense of coherence scale as a standard version to be used in Sweden (Hansson \& Cederblad, 1995). The research was mainly run by research groups located in Lund (University of Lund) and Stockholm (Karolinska Institute). There followed a period of validation of the Swedish version in different samples in different contexts (see as examples Dahlin et al., 1990; Cederblad \& Hansson, 1996; Langius \& Björvell, 1993).

However, looking at the current situation, a different image emerges. As of this writing, there is ongoing salutogenesis research at most of the universities in Sweden (Fig. 48.1).

Examining salutogenesis research in Sweden that is published either in English or in Swedish, one sees these areas of focus: clinical research related to different disease groups, nursing, aging research, workplace health, oral health, education/pedagogy and research on children and youth. Clinical research using the salutogenic approach is mainly focused on how patients are able to manage stress when suffering from serious illness such as cancer, stroke, multiple sclerosis, heart diseases, and chronic diseases generally. This research is mainly that of research groups at the Karolinska Institute, the Sahlgrenska Academy at the University of Gothenburg, and Malmö University.

The salutogenic perspective and the sense of coherence are concepts well-known in nursing research. It has its background in the time when Antonovsky visited Sweden and offered the opportunity for scientists to discuss and learn about salutogenesis. Antonovsky, in his second book, assumed that nurses would be the professional group that mainly would adopt his thoughts. This has happened generally all over the world, but particularly in Swedish nursing research, thanks to forward-thinking researchers at the Karolinska Institute in Stockholm and Umeå University. At Umeå, the focus has been mainly on aging research, and how elderly people are able to manage everyday life in the face of chronic illness.

Workplace health research has its main localization at Kristianstad University, Stockholm University, Mid-Sweden University, Jönköping University, and Karlstad University. Oral health research adopting the salutogenic approach is an area of research that emerged in the mid-2000, mainly located in Jönköping University. In educational research (pedagogics) some research groups are active at Stockholm University, University of Gothenburg, and Örebro University. Research on children and youth has continued at the University of Lund, the place where it all started, but also at Region Halland and Luleå University of Technology.

Research adopting the salutogenic approach and its core concept of the sense of coherence is extensive, and as 
Table 48.1 A selection of papers on the salutogenic concepts in Swedish

\begin{tabular}{|c|c|}
\hline Authors/title & Aims \\
\hline $\begin{array}{l}\text { Hansson, K., \& Cederblad, M. (1995). Känsla av sammanhang. Studier } \\
\text { från ett salutogent perspektiv. Skriftserie Forskning om barn och familj, } \\
\text { nr } 6\end{array}$ & $\begin{array}{l}\text { An overview of the salutogenic model of health and a research } \\
\text { synthesis of studies using the SOC questionnaire until } 1995\end{array}$ \\
\hline $\begin{array}{l}\text { Langius, A., \& Björvell, H. (1996). The salutogenic model and the use } \\
\text { of the sense of coherence scale in nursing research-a methodological } \\
\text { report. [Den salutogena modellen och användning av KASAM- } \\
\text { formuläret i omvårdnadsforskning—en metodredovisning. Vård i } \\
\text { Norden, 16(1), 28-32 }\end{array}$ & $\begin{array}{l}\text { To present the psychometrical properties of the Swedish version } \\
\text { of Sense Of Coherence (SOC) scale }\end{array}$ \\
\hline $\begin{array}{l}\text { Tishelman, C. (1996). Critical reflections over the uncritical use of } \\
\text { Antonovsky’s salutogenic model, focusing on its instrumentalisation } \\
\text { in the Sense of Coherence questionnaire. [Några kritiska reflektioner } \\
\text { över vårt okritiska bruk av mätinstrument: Exemplet Känsla av } \\
\text { Sammanhang frågeformulär]. Vård i Norden, 16(1), 33-37 }\end{array}$ & Critical reflections of the use of SOC questionnaire \\
\hline $\begin{array}{l}\text { Waad, T., \& Hult, S. (1998). Att betona det positive. Salutogen } \\
\text { kommunikation hjälper "problembarn". Omvårdaren, 5, 20-23 }\end{array}$ & $\begin{array}{l}\text { To explain how the SOC can be used in communication with asocial } \\
\text { adolescents }\end{array}$ \\
\hline $\begin{array}{l}\text { Waad, T., \& Hult, S. (2001). Att arbeta med sociala nätverkskartor } \\
\text { i ett salutogent perspektiv. En beskrivning av nätverkskartan, som } \\
\text { utredningsinstrument i öppen och sluten vård. Psyche, 4, 10-13 }\end{array}$ & $\begin{array}{l}\text { To introduce how to work with social network maps from a salutogenic } \\
\text { perspective }\end{array}$ \\
\hline $\begin{array}{l}\text { Ervér, M. A., \& Fahlström, G. (2001). It is tough having children, but } \\
\text { it's simply the best thing that ever happened to me... Focus groups } \\
\text { about community support for parents. [“Det är en pärs. . det är jobbigt } \\
\text { att ha barn, ändå är det det bästa som finns”. Fokusgrupper om stöd i } \\
\text { föräldraskap]. Vård i Norden, 21(3), 43-46 }\end{array}$ & $\begin{array}{l}\text { To gain knowledge of the need for and satisfaction with local } \\
\text { community support for parents }\end{array}$ \\
\hline $\begin{array}{l}\text { Nilsson, B., (2002). Vad betyder känsla av sammanhang i våra liv? } \\
\text { Aspekter på stabilitet, kön, hälsa och psykosociala faktorer. [Doctoral } \\
\text { thesis]. Umeå: Umeå University }\end{array}$ & $\begin{array}{l}\text { To examine the relationship between SOC and health, disease and } \\
\text { recovery among patients with stomach trouble }\end{array}$ \\
\hline $\begin{array}{l}\text { Svartvik, L., Lidfeldt, J., Nerbrand, C., et al. (2002). High sense } \\
\text { of coherence can have health enhancing effects. [Hög känsla av } \\
\text { sammanhang kan ha hälsofrämjande effekter]. Läkartidningen, } \\
\text { 99(11), 1195-1200 }\end{array}$ & $\begin{array}{l}\text { To investigate if middle-aged women with a self-reported low level } \\
\text { of SOC also differed in biological variables, from women with a high } \\
\text { level of SOC }\end{array}$ \\
\hline $\begin{array}{l}\text { Hansson, K., Johansson, P., Drott-Englén, G., \& Benderix, Y. (2004). } \\
\text { Functional family therapy in child psychiatric practice. [Funktionell } \\
\text { familjeterapi i barnpsykiatrisk praxis. Om behandling av } \\
\text { ungdomskriminalitet utanför universitetsforskningen]. } \\
\text { Nordisk Psykologi, 2004, 56(4), 304-320 }\end{array}$ & $\begin{array}{l}\text { To examine a model of cooperation in functional family therapy } \\
\text { in child psychiatric practice among asocial adolescents }\end{array}$ \\
\hline $\begin{array}{l}\text { Jakobsson, U. (2008). A brief review of the development and the } \\
\text { psychometric properties of the Sense Of Coherence scale (SOC). } \\
\text { [KASAM-instrumentets utveckling och psychometriska egenskaper- } \\
\text { en översikt]. Vård i Norden, 28(1), 53-55 }\end{array}$ & $\begin{array}{l}\text { To discuss the strengths and weaknesses regarding the instruments } \\
\text { of psychometric properties }\end{array}$ \\
\hline
\end{tabular}

already mentioned, published mostly in English. Papers in Swedish go back mainly to the 1990 s and early 2000 , when articles were published in Nordic scientific and professional journals. Nowadays there are many handbooks and textbooks in Swedish on how to use salutogenesis in everyday practice, for example, how to work according to salutogenic principles with the elderly (Westlund, 2013; Westlund \& Sjöberg, 2005, 2008). Another example is how to transform salutogenic principles and understanding in leadership in organizations (Hanson, 2010, 2015). A university-level textbook on salutogenesis in Swedish is also available (Eriksson, 2015). This is an outcome of the established of a resource center on salutogenesis established in 2011 at the University West in Trollhättan (www. salutogenesis.hv.se).

Open Access This chapter is distributed under the terms of the Creative Commons Attribution-Noncommercial 2.5 License (http:// creativecommons.org/licenses/by-nc/2.5/) which permits any noncommercial use, distribution, and reproduction in any medium, provided the original author(s) and source are credited.

The images or other third party material in this chapter are included in the work's Creative Commons license, unless indicated otherwise in the credit line; if such material is not included in the work's Creative Commons license and the respective action is not permitted by statutory regulation, users will need to obtain permission from the license holder to duplicate, adapt or reproduce the material. 


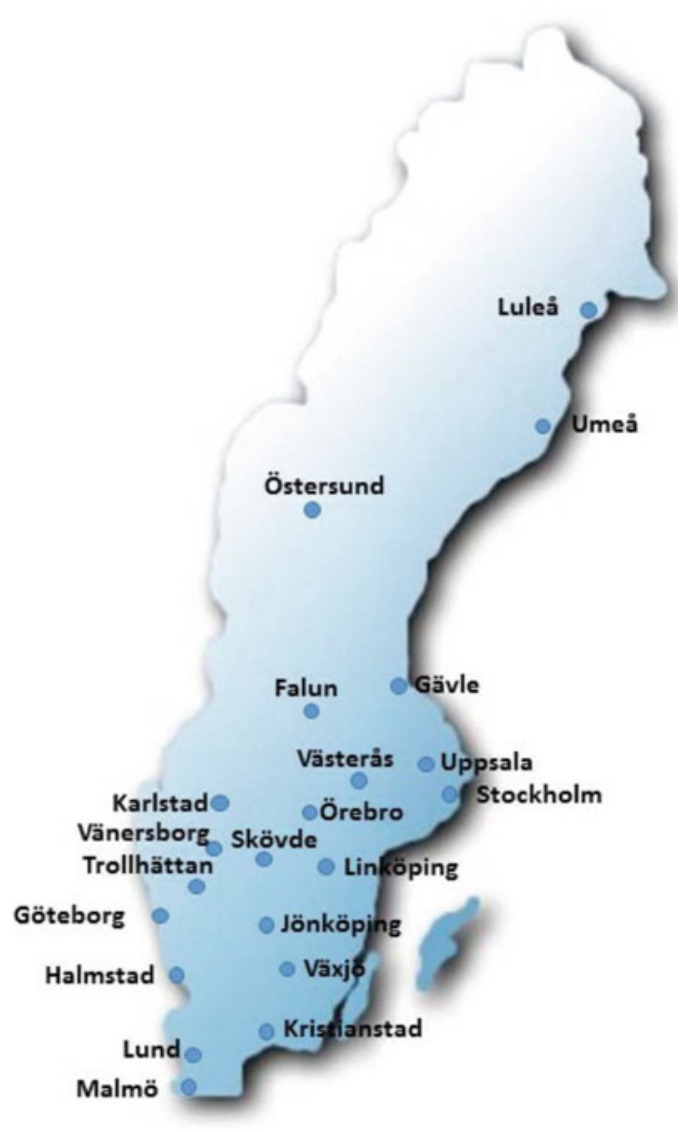

Fig. 48.1 Salutogenesis research sites in Sweden

\section{References}

Cederblad, M. (1996). The children of the Lundby study as adults: A salutogenic perspective. European Child \& Adolescent Psychiatry, 5(Suppl. 1), 38-43.

Cederblad, M. (1998). The proof of the cake is the eating. In Voices of sense of coherence. 15 scientists examine the concept of Sense of Coherence. [Röster om KASAM. 15 forskare granskar begreppet Känsla av sammanhang], pp. 45-48. Stockholm: Forskningsrådsnämden.

Cederblad, M., Dahlin, L., \& Hagnell, O. (1994). Salutogenic childhood factors reported by middle-aged individuals. Follow-up of the children from the Lundby study grown up in families experiencing three or more childhood psychiatric risk factors. European Archives of Psychiatry and Clinical Neuroscience, 244, 1-11.

Cederblad, M., \& Hansson, K. (1996). Sense of coherence-A concept influencing health and quality of life in a Swedish psychiatric at-risk group. Israel Journal of Medical Science, 32(3-4), 194-199.

Dahlin, L., \& Cederblad, M. (1993). Salutogenesis—Protective factors for individuals brought up in a high-risk environment with regard to the risk for a psychiatric or social disorder. Nordic Journal of Psychiatry, 47, 53-60.
Dahlin, L., Cederblad, M., Antonovsky, A., \& Hagnell, O. (1990). Childhood vulnerability and adult invincibility. Acta Psychiatrica Scandinavica, 82, 228-232.

Eriksson, M. (2007). Unravelling the mystery of salutogenesis. The evidence base of the salutogenic research as measured by Antonovsky's Sense of Coherence Scale. Doctoral thesis. Åbo Akademi University. Folkhälsan Research Centre, Health Promotion Research Programme, Research Report 2007:1. Turku: Folkhälsan.

Eriksson, M. (2015). Salutogenes-om hälsans ursprung. Från forskning till praktisk tillämpning. Stockholm: Liber.

Hanson, A. (2010). Salutogent ledarskap: För hälsosam framgång. Stockholm: Gothia.

Hanson, A. (2015). Salutogen kultur: Från värdegrund till verksamhetsnytta. Stockholm: Salutogent ledarskap Sverige AB.

Hansson, K., \& Cederblad, M. (1995). Känsla av sammanhang. Studier från ett salutogent perspektiv. Skriftserie Forskning om barn och familj, $\mathrm{nr}$ 6. Lund: Lunds Universitet, Institutionen för barn- och ungdomspsykiatri.

Konarski, K. (1998). Our fear of health? [Vår rädsla för hälsa?]. In Voices of sense of coherence. 15 scientists examine the concept of Sense of Coherence. [Röster om KASAM. 15 forskare granskar begreppet känsla av sammanhang], pp. 69-75. Stockholm: Swedish Research Council.

Kumlin, T. (1998). Sense of coherence in theory, empiry and criticism. [Känsla av sammanhang i teori, empiri och kritik]. Stockholm: The Swedish Research Council [Forskningsrådsnämnden].

Langius, A., \& Björvell, H. (1993). Coping ability and functional status in a Swedish population sample. Scandinavian Journal of Caring Sciences, 7, 3-10.

Langius, A., \& Björvell, H. (1996). The salutogenic model and the use of the sense of coherence scale in nursing research-A methodological report. [Den salutogena modellen och användning av KASAM-formuläret i omvårdnadsforskning-en metodredovisning]. Vård i Norden, 16(1), 28-32.

Langius, A., \& Björvell, H. (2001). The applicability of the Antonovsky's sense of coherence scale to a group of Pentecostalists. Scandinavian Journal of Caring Sciences, 15, 190-192.

Langius, A., Björvell, H., \& Antonovsky, A. (1992). The sense of coherence concept and its relation to personality traits in Swedish samples. Scandinavian Journal of Caring Sciences, 6(3), 165-171.

Lindström, B. (1994). The essence of existence. On the quality of life of children in the Nordic countries-Theory and practice in public health. Doctoral thesis, Nordic School of Public Health, Gothenburg.

Lindström, B. (2006). Professor Bengt Lindström, Inaugural address at NHV, Göteborg. Installationstal vid NHV, Göteborg. http:// docplayer.se/10717438-Halsan-i-livets-flod-installationstal-av-bengtlindstrom-professor.html.

Röster om KASAM. 15 forskare granskar begreppet Känsla av sammanhang. (1998). Stockholm: Forskningsrådsnämden.

Westlund, P. (2013). Salutogen hemtjänst och hemsjukvård. Stockholm: Gothia Fortbildning.

Westlund, P., \& Sjöberg, A. (2005). Antonovsky inte Maslow-för en salutogen omsorg och vård. Stockholm: Fortbildningsförlaget.

Westlund, P., \& Sjöberg, A. (2008). Planera för mirakel: Arbeta salutogent, stärk Kasam. Stockholm: Fortbildningsförlaget. 